\title{
HUBUNGAN PERAN SUAMI DAN PETUGAS KESEHATAN DENGAN KETERATURAN ANTENATAL CARE (ANC) PADA IBU HAMIL TRIMESTER III DI PUSKESMAS ARJASA JEMBER
}

\author{
Sri Widya*, Sri Utami**, Fitriana Putri** \\ * Mahasiswa S1 Keperawatan Fakultas Ilmu Kesehatan UNMUH Jember \\ **Dosen Fakultas Ilmu Kesehatan Universitas Muhammadiyah Jember \\ sriwidya1707@gmail.com
}

\begin{abstract}
ABSTRAK
Peran suami adalah seorang pemimpin dan pelindung bagi istrinya denga mendidik, mengarahkan istri pada kebenaran. Petugas kesehatan, seseorang yang bertanggung jawab dalam memberikan pelayanan kesehatan kepada individu, keluarga dan masyarakat. Antenatal Care (ANC) pemeriksaan kehamilan untuk mengetahui keadaan ibu dan janin secara berkala terhadap penyimpangan yang ditemukan pada ibu hamil. Metode yang digunakan adalah pendekatan Cross Sectional bertujuan untuk mengetahui hubungan peran suami dan petugas kesehatan pada keteraturan Antenatal Care (ANC) ibu hamil trimester III di Puskesmas Arjasa Jember. Populasi pada penelitian ini sebanyak 55 responden. Teknik pengambilan sampel menggunakan Cluster Random Sampling. Teknik pengumpulan data menggunakan kuisioner dan dokumentasi buku KIA. Hasil analisa data peran suami didapatkan nilai $P$ Value: 0,003 artinya $\mathrm{H}_{1}$ diterima, dan peran petugas kesehatan didapatkan nilai $P$ Value Fisher's Exact Test: 0,002 artinya $\mathrm{H}_{1}$ diterima, ada hubungan peran petugas kesehatan pada keteraturan Antenatal Care (ANC) ibu hamil trimester III di Puskesmas Arjasa Jember. Ada hubungan peran suami dan peran petugas kesehatan pada keteraturan Antenatal Care (ANC) ibu hamil trimester III di Puskesmas Arjasa Jember. Dengan demikian optimalisasi peran suami dan petugas kesehatan sangat diperlukan untuk keteraturan ANC.
\end{abstract}

Kata kunci : Peran Suami; Peran Petugas Kesehatan; Antenatal Care (ANC)

\section{ABSTRACT}

Husbands take their roles as leaders and protectors of their wives through educating and leading them to the right path. Health workers, on the other hand, are responsible for providing health care to individuals, families, and societies. Antenatal Care (ANC) is pregnancy checking aimed to diagnose the condition of mothers and fetus periodically against any possible deviations found during the pregnancy. The study used cross sectional approach aiming to identify relationship of roles of husbands and health workers with regularity of Antenatal Care $(A N C)$ of pregnant women in their third trimester in the Community Health Center of Arjasa Jember. The population of the study is 55 respondents, while the 
sampling technique used was Cluster Random Sampling. The data were collected with questionnaire and documentation of KIA book (recording mother and child's health). The analysis of husband's roles resulted the P Value: 0,003 meaning that $H_{1}$ is accepted, and that of the health workers yielded the P Value Fisher's Exact Test: 0,002 where $H_{1}$ is accepted. There is relationship between the roles of husbands and health workers and the regularity of Antenatal Care (ANC) of pregnant women in their third trimester in the Community Health Center of Arjasa Jember. There is relationship between the roles of husbands and health workers with the regularity of Antenatal Care (ANC) of pregnant women in their third trimester in the Community Health Center of Arjasa Jember. It is suggested that the board of managers of the Community Health Center improve the socialization about the importance of checking pregnancy through printed media like leaflet and so on.

Keywords: Husband's roles; Health workers roles; Antenatal Care (ANC)

\section{PENDAHULUAN}

Kehamilan merupakan peristiwa alamiah. Setiap kehamilan tentu saja perlu perhatian khusus, sebab mungkin saja rawan bagi ibu atau janin dalam kandungan. Oleh karena itu, ibu perlu mengenal berbagai hal yang akan ibu alami per trimester serta langkah yang tepat untuk mengatasinya (Maulana, mirza 2008). Pada proses kehamilan perlu melakukan kunjungan pemeriksaan yang disebut dengan ANC (Antenatal Care) mulai dari pemeriksaan $\mathrm{K} 1$ sampai dengan K4. Berdasarkan pedoman SPM Bidang Kesehatan 2009 menyebutkan bahwa cakupan kunjungan ibu hamil K4 adalah cakupan ibu hamil yang telah memperoleh pelayanan (Antenatal Care) sesuai dengan standar paling sedikit 4 kali diwaktu tertentu (Depkes RI, 2016).

Manajemen keperawatan dalam pelayanan kesehatan merupakan sebuah pengendalian terhadap pengawasan dan pengontrolan. Dalam hal ini seorang perawat atau petugas kesehatan mempunyai sebuah pengendalian mutu terhadap manajemen keperawatan dimana dalam pelayanan kesehatan perawat memiliki tanggung jawab untuk mewujudkan pelayanan yang berkualitas, inovatif, dan kreatif demi memberikan pelayanan sesuai standar asuhan keperawatan (Bakri, 2017).

Cakupan K1 sampai dengan K4 terjadi kesenjangan yaitu tidak semua ibu hamil melakukan kunjungan pelayanan Antenatal Care (ANC) dengan teratur hingga kunjungan ke 4. Sedangkan target yang harus dicapai yaitu sebesar 93\%. Puskesmas dengan cakupan kunjungan ibu hamil K4 yang terendah adalah Puskesmas Arjasa Jember sebesar $47 \%$.

Pelayanan Antenatal Care (ANC) memerlukan adanya dukungan dari peran suami atau keluarga untuk melakukan pemeriksaan kunjungan mulai kunjungan pertama hingga pada kunjungan ke-4 serta pentingnya salah satu peran dari petugas kesehatan yaitu sebuah pelayanan terhadap ibu hamil. Kehamilan dapat terkontrol dengan baik jika angka 
kematian ibu dan anak dapat ditekan dengan teraturnya melakukan pemeriksaan kehamilan mulai kunjungan pertama hingga kunjungan ke-4.

Berdasarkan uraian diatas maka peneliti ingin menganalisa hubungan peran suami dan petugas kesehatan dengan keteraturan Antenatal Care (ANC) ibu hamil Trimester III di Puskesmas Arjasa Jember.

\section{METODE PENELITIAN}

Desain yang digunakan adalah korelasi dengan pendekatan cross sectional. Penelitian dilaksanakan untuk mengembangkan hubungan antar variabel dan menjelaskan hubungan yang ditemukan (Nursalam, 2008).

Populasi dalam penelitian ini adalah ibu hamil yang terpilih pada 43 posyandu di Wilayah Kerja Puskesmas Arjasa Jember. Besar sampel didapatkan 55 jumlah ibu hamil trimester III yang melakukan kunjungan Antenatal Care (ANC). Penelitian ini menggunakan teknik pengambilan sampel Probability Sampling dengan pendekatan Cluster Random Sampling yaitu pengambilan sampel dilakukan secara pengelompokkan berdasarkan wilayah atau lokasi dari populasi (Nursalam, 2008).

Teknik pengumpulan data dalam penelitian ini menggunakan kuisioner dan dokumentasi buku KIA. Penelitian ini dilakukan di Posyandu terpilih di Wilayah Kerja Puskesmas Arjasa Jember mulai bulan November - Desember 2018. Waktu penelitian dilaksanakan mulai bulan November - Desember 2018. Variabel tunggal dalam penelitian ini adalah berdasarkan karakteristik individu pada responden.

Uji hipotesis yang digunakan adalah uji Chi Square. Untuk mengetahui hubungan antara peran suami dan petugas kesehatan dengan keteraturan Keteraturan Antenatal Care (ANC) pada ibu hamil trimester III maka peneliti harus memenuhi beberapa syarat dengan nilai signifikan yaitu $\alpha(0,05)$.

\section{HASIL}

Hasil penelitian ini sebagai berikut:

Tabel 1: Distribusi Usia Ibu Hamil Trimester III di Puskesmas Arjasa Kabupaten Jember Tahun 2018

\begin{tabular}{lcc}
\hline Usia ibu & f & Persentase \\
\hline$<20$ th & 29 & 52,7 \\
$>35$ th & 12 & 21,8 \\
$20-35$ th & 14 & 25,5 \\
\hline Total & 55 & 100
\end{tabular}

Berdasarkan distribusi data diketahui bahwa jumlah terbanyak usia ibu hamil yaitu $<20$ tahun sebanyak 29 orang $(52,7 \%)$. 
Tabel 2: Distribusi Suku Ibu Hamil Trimester III di Puskesmas Arjasa Kabupaten Jember Tahun 2018

\begin{tabular}{lcc}
\hline Jenis suku & $\mathrm{f}$ & Persentase \\
\hline Suku lain & 1 & 1,8 \\
Madura & 38 & 70,4 \\
Jawa & 15 & 27,3 \\
\hline Total & 55 & 100 \\
\hline
\end{tabular}

Berdasarkan distribusi data diketahui sebagian besar jumlah jenis suku terbanyak ialah Madura sebanyak 38 orang $(70,4 \%)$.

Tabel 3: Distribusi Tingkat Pendidikan Ibu Hamil Trimester III di Puskesmas Arjasa Kabupaten Jember Tahun 2018

\begin{tabular}{lcc}
\hline Pendidikan & f & Persentase \\
\hline SD & 29 & 52,7 \\
SMP & 21 & 38,2 \\
SLTA & 5 & 9,1 \\
\hline Total & 55 & 100 \\
\hline
\end{tabular}

Berdasarkan distribusi diketahui jumlah terbanyak tingkat pendidikan responden adalah Sekolah Dasar sebanyak 29 orang $(52,7 \%)$.

Tabel 4: Distribusi Pekerjaan Ibu Hamil Trimester III di Puskesmas Arjasa Kabupaten Jember Tahun 2018

\begin{tabular}{lcc}
\hline Pekerjaan & $\mathrm{f}$ & Persentase \\
\hline Ibu rumah tangga & 53 & 96,4 \\
Swasta & 1 & 1,8 \\
PNS & 1 & 1,8 \\
\hline Total & 55 & 100 \\
\hline
\end{tabular}

Berdasarkan distribusi bahwa totalitas tingkat pekerjaan terbanyak yaitu Ibu Rumah Tangga sebanyak 53 orang $(96,4 \%)$.

Tabel 5: Distribusi Pendamping Saat ANC Ibu Hamil Trimester III di Puskesmas Arjasa Kabupaten Jember Tahun 2018

\begin{tabular}{lcc}
\hline Menemani ibu periksa & $\mathrm{f}$ & Persentase \\
\hline Sendiri & 17 & 30,9 \\
Teman & 9 & 16,4 \\
Saudara & 7 & 12,7 \\
Suami & 20 & 36,4 \\
\hline Total & 55 & 100 \\
\hline
\end{tabular}


Berdasarkan distribusi bahwa jumlah terbanyak frekuensi yang menemani ibu hamil periksa yaitu kategori suami sebanyak 20 orang $(36,4 \%)$.

Tabel 6: Distribusi Tempat Pemeriksaan Ibu Hamil Trimester III di Puskesmas Arjasa Kabupaten Jember Tahun 2018

\begin{tabular}{lcc}
\hline Tempat pemeriksaan & $\mathrm{f}$ & Persentase \\
\hline Rumah sakit & 1 & 1,8 \\
Puskesmas & 9 & 16,4 \\
Bidan/dokter/perawat & 45 & 81,8 \\
& & \\
\hline Total & 55 & 100 \\
\hline
\end{tabular}

Berdasarkan distribusi diketahui sebagian besar jumlah terbanyak tempat pemeriksaan adalah dengan Bidan/dokter/perawat sebanyak 45 orang $(81,8 \%)$.

Tabel 7: Distribusi Jarak Rumah Ibu Hamil Trimester III di Puskesmas Arjasa Kabupaten Jember Tahun 2018

\begin{tabular}{lcc}
\hline Jarak rumah & f & Persentase \\
\hline $5-10 \mathrm{~km}$ & 1 & 1,9 \\
$<5 \mathrm{~km}$ & 54 & 98,2 \\
\hline Total & 55 & 100 \\
\hline
\end{tabular}

Berdasarkan distribusi diketahui totalitas frekuensi terbanyak Jarak Rumah responden yaitu $<5 \mathrm{~km}$ sebanyak 54 orang $(98,2 \%)$.

Tabel 8: Distribusi Penghasilan Ibu Hamil Trimester III di Puskesmas Arjasa Kabupaten Jember Tahun 2018

\begin{tabular}{lcc}
\hline Penghasilan & f & Persentase \\
\hline <Rp.1.950.000 & 52 & 94,5 \\
>Rp. 1.950.000-Rp.2.500.000 & 1 & 1,8 \\
>Rp.2.500.000-Rp.5.000.000 & 2 & 3,6 \\
\hline Total & 55 & 100 \\
\hline
\end{tabular}

Berdasarkan distribusi terdapat totalitas jumlah penghasilan terbanyak yaitu $<$ Rp. 1.500 .000 sebanyak 52 orang $(94,5 \%)$.

Tabel 9: Distribusi Peran Suami Ibu Hamil Trimester III di Puskesmas Arjasa Kabupaten Jember Tahun 2018

\begin{tabular}{lcc}
\hline Peran suami & f & Persentase \\
\hline Tidak Optimal & 14 & 25,5 \\
Optimal & 41 & 74,5 \\
\hline Total & 55 & 100 \\
\hline
\end{tabular}


Berdasarkan distribusi diketahui sebagian besar jumlah peran suami dengan kategori optimal adalah 41 orang $(74,5 \%)$.

Tabel 10: Distribusi Peran Petugas Kesehatan di Puskesmas Arjasa Kabupaten Jember Tahun 2018

\begin{tabular}{lcc}
\hline Peran petugas kesehatan & $\mathrm{f}$ & Persentase \\
\hline Tidak Optimal & 13 & 23,6 \\
Optimal & 42 & 76,4 \\
\hline Total & 55 & 100 \\
\hline
\end{tabular}

Berdasarkan distribusi diketahui sebagian besar peran petugas kesehatan dengan kategori optimal sebanyak 42 orang $(76,4 \%)$.

Tabel 11: Distribusi Keteraturan ANC Ibu Hamil Trimester III di Puskesmas Arjasa Kabupaten Jember Tahun 2018

\begin{tabular}{lcc}
\hline Keteraturan Antenatal Care $(\mathrm{ANC})$ & $\mathrm{f}$ & Persentase \\
\hline Tidak Teratur & 20 & 36,4 \\
Teratur & 35 & 63,6 \\
\hline Total & 55 & 100 \\
\hline
\end{tabular}

Berdasarkan distribusi diketahui sebagian besar jumlah keteraturan Antenatal Care (ANC) yang teratur yaitu sebanyak 35 orang $(63,6 \%)$.

Tabel 12: Hubungan Peran Suami dengan Keteraturan ANC

\begin{tabular}{|c|c|c|c|c|c|c|c|}
\hline \multirow{3}{*}{$\begin{array}{l}\text { Peran } \\
\text { suami }\end{array}$} & \multicolumn{4}{|c|}{ Keteraturan ANC } & \multirow{2}{*}{\multicolumn{2}{|c|}{ Total }} & \multirow{3}{*}{$\begin{array}{c}\mathrm{P} \\
\text { Value }\end{array}$} \\
\hline & \multicolumn{2}{|c|}{$\begin{array}{l}\text { Tidak } \\
\text { Teratur }\end{array}$} & \multicolumn{2}{|c|}{ Teratur } & & & \\
\hline & $\mathrm{f}$ & $\%$ & $\mathrm{f}$ & $\%$ & $\mathrm{f}$ & $\%$ & \\
\hline $\begin{array}{l}\text { Tidak } \\
\text { Optimal }\end{array}$ & 0 & 0 & 14 & 25,5 & 14 & 25,5 & \\
\hline Optimal & 20 & 36,4 & 21 & 38,2 & 41 & 74,5 & 0,003 \\
\hline Total & 20 & 36,4 & 35 & 63,6 & 55 & 100 & \\
\hline
\end{tabular}

Berdasarkan Crosstabulation diketahui bahwa jumlah terbanyak peran suami memiliki kategori optimal sebanyak 21 orang $(38,2 \%)$. Hasil analisis didapatkan nilai $P$ Value : 0,003 artinya $\mathrm{H}_{1}$ diterima, ada hubungan peran suami pada keteraturan Antenatal Care (ANC) ibu hamil trimester III di Puskesmas Arjasa Jember. 
Tabel 13: Hubungan Peran Petugas Kesehatan dengan Keteraturan ANC

\begin{tabular}{lccccccc}
\hline \multirow{2}{*}{$\begin{array}{c}\text { Peran } \\
\text { Petugas } \\
\text { Kesehatan }\end{array}$} & \multicolumn{4}{c}{ Keteraturan ANC } & \multicolumn{2}{c}{ Tidak } & \multicolumn{2}{c}{ Teratur } & & Total & \multirow{2}{P}{$\begin{array}{c}\text { Teratur } \\
\text { Value }\end{array}$} \\
\cline { 2 - 6 } & $\mathrm{f}$ & $\%$ & $\mathrm{f}$ & $\%$ & $\mathrm{f}$ & $\%$ & \\
\hline Tidak & 0 & 0 & 13 & 23,6 & 13 & 23,6 & \\
Optimal & 20 & 36,4 & 22 & 40,0 & 42 & 76,4 & 0,002 \\
Optimal & 20 & 36,4 & 35 & 63,6 & 55 & 100 & \\
\hline Total & & & & & & & \\
\hline
\end{tabular}

Berdasarkan Crosstabulation diketahui bahwa jumlah terbanyak peran petugas kesehatan memiliki kategori optimal sebanyak 22 orang $(40,0 \%)$. Hasil analisis didapatkan nilai $P$ Value : 0,002 artinya $\mathrm{H}_{1}$ diterima, ada hubungan peran petugas kesehatan pada keteraturan Antenatal Care (ANC) ibu hamil trimester III di Puskesmas Arjasa Jember.

\section{PEMBAHASAN}

Berdasarkan hasil analisis data yang dilakukan pada seluruh sampel penelitian sebanyak 55 responden, diketahui bahwa sebagian besar jumlah peran suami dengan kategori optimal adalah 41 orang (74,5\%). Hasil tersebut menunjukkan bahwa responden menilai sebagian besar peran suami berperan optimal pada keteraturan Antenatal Care (ANC) ibu hamil trimester III di Puskemas Arjasa Jember. Peran suami dalam kehamilan istri yaitu suatu hal yang berpengaruh dan berperan langsung dalam menjaga kesehatan ibu selama kehamilan dimana seorang ibu hamil membutuhkan pendamping selama proses kehamilan (Yulistina, 2018). Sejalan dengan penelitian yang dilakukan oleh (Priskhila Ayu, 2015) bahwa dari hasil penelitian menunjukkan ada hubungan secara bermakna antara status bekerja suami dengan peran suami selama proses kehamilan yaitu suami rutin menemani atau mengantar istrinya untuk periksa kehamilan ke tempat pelayanan kesehatan $\geq 4$ kali.
Hasil penelitian yang dilakukan terhadap 55 responden ibu hamil trimester III di Puskesmas Arjasa Jember diperoleh data sebagian besar peran petugas kesehatan memiliki kategori optimal sebanyak 42 orang $(76,4 \%)$. Hasil ini menunjukkan bahwa seluruh responden mengatakan peran petugas kesehatan memiliki peran yang optimal. Petugas kesehatan merupakan seseorang yang bertanggung jawab dalam memberikan pelayanan kesehatan kepada individu, keluarga dan masyarakat serta memiliki kewenangan dalam melakukan upaya dan mencakup seluruh proses kesehatan manusia (Alimul Aziz, 2014 dalam Betan, 2013). Kegiatan terkait peran petugas kesehatan yang optimal ini juga dilatar belakangi oleh pekerjaan ibu hamil. Berdasarkan data demografi dengan kategori pekerjaan ibu rumah tangga memiliki jumlah terbanyak yaitu 53 orang $(96,4 \%)$. Menurut peneliti, bahwasanya pekerjaan ibu juga memiliki pengaruh dengan mempunyai waktu yang luang untuk dapat mengatur kunjungan Antenatal 
Care (ANC). Hal ini sejalan dengan penelitian yang dilakukan oleh (Jane, M Pangemanan, 2014) bahwa terdapat hubungan antara karakteristik ibu hamil (pekerjaan) dengan pemanfaatan pelayanan $\mathrm{K} 1$ dan K4.

Berdasarkan hasil penelitian keteraturan Antenatal Care (ANC) ibu hamil trimester III di Puskesmas Arjasa Jember sebagian besar jumlah keteraturan Antenatal Care (ANC) memiliki kategori optimal sebanyak 35 orang $(63,6 \%)$. Hal ini menunjukkan sebagian besar responden teratur melakukan kunjungan Antenatal Care (ANC). Keteraturan Antenatal Care (ANC) merupakan pemeriksaan kehamilan yang dilakukan untuk memeriksa keadaan ibu dan janin secara berkala yang diikuti dengan upaya koreksi terhadap penyimpangan yang ditemukan untuk menjaga kesehatan ibu dan janinnya (Sarwono, 2002 dalam Indriyani, 2013). Potensi lain yang mendukung ibu hamil untuk melakukan kunjungan Antenatal Care (ANC) yaitu ditinjau dari data demografi berdasarkan jarak rumah < $5 \mathrm{~km}$ sebanyak 54 orang $(98,2 \%)$. Hal ini termasuk keterjangkauan masyarakat dalam mengunjungi fasilitas kesehatan melalui jarak tempuh yang dekat. Berdasarkan penelitian yang dilakukan oleh (Kurnia Indriyanti, 2017) untuk jarak tempuh antara rumah dengan pusat pelayanan Antenatal Care (ANC) yang dekat sebagian besar teratur dalam kunjungan Antenatal Care (ANC).

Hasil analisa data peran suami yang dilakukan pada seluruh sampel penelitian sebanyak 55 responden diketahui bahwa sebagian besar responden mengatakan peran suami dalam kategori optimal sebanyak $41(74,5 \%)$, dan responden yang mengatakan peran suami tidak optimal sebanyak 14 (25,5\%). Hasil tersebut menunjukkan bahwa sebagian besar responden mengatakan peran suami dalam kategori yang optimal di Wilayah Kerja Puskesmas Arjasa Jember. Hasil penelitian ini menunjukkan bahwa nilai $P$ Value : 0,003 artinya $\mathrm{H}_{1}$ diterima, yaitu ada hubungan antara peran suami dengan keteraturan Antenatal Care (ANC) pada Ibu Hamil Trimester III. Berkaitan dengan peran suami dalam ketegori optimal dengan keteraturan Antenatal Care (ANC) sebanyak 20 orang $(36,4 \%)$ yaitu ditinjau dari data demografi. Penelitian terkait menurut (Effi M Hafidz, 2007) yang menyatakan bahwa selama ibu mengandung, diperlukan dukungan dan perhatian serta kerelaan untuk melakukan kerjasama dalam mengurus rumah tangga dari suami.

Hasil penelitian peran petugas kesehatan didapatkan sebagian besar menunjukkan bahwa dari 55 jumlah responden yang mengatakan peran petugas kesehatan dalam kategori optimal sebanyak 42 orang $(76,4 \%)$. Berdasarkan penelitian yang telah dilakukan bahwa hasil penelitian ini mendapatkan nilai $P$ Value : 0,002 sehingga dapat disimpulkan bahwa $\mathrm{H}_{1}$ dterima, yang artinya ada hubungan antara petugas kesehatan pada keteraturan Antenatal Care (ANC) Ibu Hamil Trimester III di Wilayah Kerja Puskesmas Arjasa Jember. Petugas kesehatan adalah salah satu hal yang berpengaruh terhadap keberhasilan suatu program atau kegiatan untuk memiliki peran dalam memfasilitasi dan memotivasi masyarakat dalam program kesehatan. Khusus Antenatal Care (ANC) apabila ibu hamil tidak rutin 
melakukan pemeriksaan atau pemantauan kehamilan sesuai jadwal yang telah ditentukan oleh petugas kesehatan maka akan menimbulkan dampak yang tidak baik bagi ibu dan janin (Novita, Franciska dalam Suci Aprilliyana, 2011).

\section{SIMPULAN}

Setelah dilakukan penelitian dan uji statistik terhadap hipotesa tentang peran suami dan petugas kesehatan pada keteraturan Antenatal Care (ANC) ibu hamil trimester III di Wilayah Kerja Puskesmas Arjasa Jember, maka dapat disimpulkan bahwa peran suami dan petugas kesehatan pada keteraturan Antenatal Care (ANC) ibu hamil trimester III sebagian besar optimal. Keteraturan Antenatal Care (ANC) ibu hamil trimester III sebagian besar teratur. Hasil analisis didapatkan nilai $P$ Value: 0,003 artinya $\mathrm{H}_{1}$ diterima, dan ada hubungan peran suami pada keteraturan Antenatal Care (ANC) ibu hamil trimester III di Puskesmas Arjasa Jember. Hasil analisis lainnya didapatkan nilai $P$ Value Fisher's Exact Test: 0,002 dimana $\mathrm{H}_{1}$ diterima, artinya ada hubungan peran petugas kesehatan pada keteraturan Antenatal Care (ANC) ibu hamil trimester III di Puskesmas Arjasa Jember.

\section{SARAN}

Berdasarkan penelitian yang telah dilakukan, disarankan bagi:

\section{Ibu Hamil}

Ibu hamil disarankan ikut serta dalam program penyuluhan terkait Antenatal Care (ANC) untuk lebih meningkatkan pengetahuan agar ibu hamil mengetahui pentingnya melakukan pemeriksaan kehamilan.

Suami

Untuk suami disarankan dapat berperan serta dalam memberikan dukungan terhadap ibu dengan cara mengantar, mengingatkan ibu untuk memeriksakan kehamilan secara teratur.

\section{Instansi Kesehatan}

Petugas kesehatan khususnya di Puskesmas Arjasa Jember untuk meningkatkan penyuluhan tentang permeriksaan kehamilan kepada masyarakat oleh bidan maupun tenaga promosi kesehatan dan didukung dengan sarana prasarana yang lebih baik diantaranya menggunakan media cetak leaflet, poster, koran dan media informasi lainnya, sehingga pengetahuan masyarakat khususnya ibu hamil menjadi meningkat terkait pentingnya melakukan pemeriksaan kehamilan secara lengkap.

\section{Intitusi Pendidikan}

Disarankan dapat meningkatkan pendidikan kesehatan dengan berbagai problem terkait kesehatan ibu dan anak sehingga dapat berpartisipasi aktif dalam meningkatkan derajat kesehatan ibu selama kehamilan, dengan memberikan berbagai informasi dan edukasi kesehatan khusunya ibu hamil.

\section{Bagi Peneliti Selanjutnya}

Peneliti selanjutnya dapat mengembangkan penelitian ini dengan berbagai desain penelitian 
serta melakukan uji validitas dan reliabilitas dengan jumlah responden minimal 30 responden, sehingga hasil penelitian menjadi lebih baik. Selain itu peneliti selanjutnya dapat menggunakan desian penelitian dengan judul "Faktor-faktor yang Berhubungan dengan Fungsi Komunikatif Pelayanan Kesehatan terhadap Keteraturan Antenatal Care (ANC) pada Ibu Hamil.

\section{DAFTAR PUSTAKA}

Bakri, M. H. (2017). Manajemen Keperawatan Konsep dan Aplikasi alam Praktik Keperawatan Profesional. Yogyakarta: Pustaka Baru Press.

Departemen Kesehatan, (2016). Standar Pelayanan Minimal Bidang Kesehatan. (https://djsn.go.id diperoleh tanggal 25 Agustus 2018).

Hafidz, E. M., Kesehatan, D., \& Jawa, P. (2007). Hubungan Peran Suami Dan Orang Tua Dengan Perilaku Ibu Hamil Dalam Pelayanan Antenatal Dan Persalinan Di Wilayah Puskesmas Kecamatan Sedan Kabupaten Rembang, 2(2).

Indriyani, D. (2013). Keperawatan Maternitas Pada Area Perawatan Antenatal, Edisi 1, Yogyakarta: Graha Ilmu.

Indriyanti dan Padila. (2014). Analisis Faktor Yang Berpengaruh Terhadap Kunjungan Antenatal Care. (https://jurnalonline.lppmdianh usada.ac.id, diperoleh pada tanggal 20 Januari 2019).

Maulana, M. (2008). Buku Pegangan Ibu Panduan dan Lengkap Kehamilan, Kata Hati, Yogyakarta.
Novita dan Franciska, (2011). Promosi Kesehatan dalam Pelayanan Kebidanan. Jakarta: Salemba Medika.

Nursalam, (2008). Konsep dan Penerapan Metodologi Penelitian Ilmu Keperawatan. Pedoman Skripsi, Tesis, dan Instrumen Penelitian Keperawatan. Jakarta: Salemba Medika.

Pangemanan, Jane M, (2014). Hubungan Antara Karakteristik Ibu Hamil dengan Pemanfaatan Pelayanan $K 1$ dan $K 4$. (http://fkm.unsrat.ac.id/, diperoleh pada tanggal 29 Januari 2018).

Yulistina, (2018). Peran Suami Selama Kehamilan. (https://bidanku.com, diperoleh tanggal 26 Mei 2018). 